\title{
Las potestades municipales y los bienes culturales: la reivindicación de la organización administrativa local
}

\author{
Orlando Vignolo Cueva
}

\section{RESUMEN}

El presente trabajo examina las bases del derecho peruano de los bienes culturales, como un derecho administrativo especial material y orgánicamente. Es así como, además de ciertas cuestiones relacionadas con la organización administrativa, se acude a los conceptos de bienes culturales de los municipios y los bienes privados de interés público-cultural, como los urbanos que son de competencia local. Las reflexiones aquí contenidas se cuestionan acerca del rumbo que ha tomado la legislación peruana, con el fin de insistir en la importancia de encontrar un equilibrio entre las relaciones y las responsabilidades que actualmente comparten el Ministerio de Cultura y las municipalidades en el desarrollo de actividades tendientes a preservar y proteger los bienes que integran el patrimonio cultural de la nación.

1 Profesor de la Facultad de Derecho de la Universidad de Piura, Piura, Perú. Director de la Revista Anuario de la Función Pública. Abogado del Estudio Echecopar, Lima, Perú. Doctor en Derecho la Universidad de Zaragoza, Zaragoza, España. Correo-e: orlando.vignolo@ udep.pe. Enlace ORCID: https://orcid.org/0000-0003-1134-651x. Fecha de recepción: 15 de agosto de 2018. Fecha de modificación: 5 de septiembre de 2018. Fecha de aceptación: 24 de septiembre de 2018. Para citar el artículo: Vignolo Cueva, Orlando, "Las potestades municipales y los bienes culturales: la reivindicación de la organización administrativa local", Revista digital de Derecho Administrativo, Universidad Externado de Colombia, n. ${ }^{\circ} 21$, 2019, pp. 371-400. DOI: https://doi.org/10.18601/21452946.n21.15 
Palabras clave: bienes culturales, bienes privados de interés cultural, patrimonio histórico, urbanismo, organización administrativa, potestades municipales.

\title{
Municipal Authority and Cultural Property: The Vindication of The Local Administrative Organization
}

\begin{abstract}
This paper explores the foundations of Peruvian Law concerning cultural goods, as a structural and material special field of Administrative Law. Besides examining certain questions related to administrative organization, it appeals to the concepts of cultural property of municipalities and private property of public cultural interest, such as the urban property, which are under the dominion of local authorities. The arguments asserted in this document question the path Peruvian legislation has pursued, in order to recall the importance of attaining a balance in the relations and duties currently shared by the Ministry of Culture and local municipalities in the preservation and protection of the national cultural heritage.

Keywords: Cultural Property, Private Property of Cultural Public Interest, Historic Heritage, Urbanism, Organization of the Public Administration, Local Municipal Power.
\end{abstract}

\section{BASES CONCEPTUALES DE LOS BIENES CULTURALES. UNA POLÉMICA PRIMACÍA DEL ESTADO POR SOBRE LAS MUNICIPALIDADES EN LA GESTIÓN DE LOS BIENES CULTURALES (PRINCIPALMENTE URBANOS)}

El sabio italiano Antonio Raimondi describió gráficamente al patrimonio cultural, natural e histórico peruano a partir de una frase que se le atribuye como parte de su obra científica y de investigación, aunque sigan existiendo dudas si realmente fue ideada y puesta en sus escritos, o por el contrario surgió desde el propio acervo popular. La famosa expresión en cuestión es la siguiente: "el Perú es un mendigo sentado en un banco de oro". Quizás, sin variar el alcance y tonalidad de la frase, pueda agregarse que esta Nación vive rodeada de bienes culturales de toda índole, valor, de distintos orígenes ligados a múltiples intervenciones de florecimiento (no solo inca) y, como no, con antigüedades que van más atrás a los 8000 a. C. Todas estas cuestiones solo muestran una enorme obligación de la sociedad peruana actual en pos de salvaguardar y hacer transcender un legado conformado por las antiguas culturas preincas, el inmenso patrimonio del Imperio inca, el mestizaje cultural producido con la conquista española, el no menos relevante patrimonio republicano de inicios 
del siglo XIX y XX, entre otras manifestaciones materiales de un antiguo espíritu civilizador forjado en este territorio.

Por ejemplo, solo en patrimonio cultural e histórico urbano, muchas urbes peruanas de fundación española y creadas en medio de un proceso racional y jurídico denominado por el profesor Brewer-Carías como la "ciudad ordenada"2, comparten una herencia común por la "planta urbana reticular, con plaza mayor como punto de inicio de la trama urbana de la cual salían las calles rectas, formando un damero" ${ }^{\prime \prime}$. Es más, muchas de estas ciudades (tales como Lima, Arequipa, Trujillo, Huamanga, Jauja y Lambayeque, entre otras) formaron parte de uno de los principales virreinatos del Imperio español (incluso considerado como un reino en sí mismo $)^{4}$, con lo cual acumularon una inmensa cantidad de bienes urbanos, monumentos de gran nivel y un paisaje urbano que merecen ser estudiados, puestos en valor y conocidos por terceros. Es más, mucho de este patrimonio cultural aparece configurado mediante un paisaje citadino único, que mezcla la raíz hispánica con restos arqueológicos preincas e incas de gran calaje (como pasa, entre otras, con la ciudad imperial del Cuzco o las urbes de Trujillo y Lambayeque, que tienen muy cerca de sus centros o plazas principales a los centros ceremoniales de barro Muchik y Chimú).

Estas obligaciones descritas (de múltiples aristas), pero principalmente centrada en las labores de defensa y salvaguarda de todo tipo, exigible en muchas formas a los miembros de la sociedad actual (concretizado en los propios ejercicios y las correspondientes delimitaciones de los derechos pertinentes de los ciudadanos peruanos), se establece tras un componente intergeneracional que podría entenderse como: "una dimensión universalista, fundada en que una motivación de tal protección es preservar ese patrimonio para las generaciones futuras $[\ldots]$ porque se trata de un patrimonio cultural de la humanidad" ${ }^{\prime \prime}$.

Las exigencias en cuestión se han trasladado también de manera efectiva a todos los poderes públicos existentes, a partir de principios y reglas aparecidas no solo en instrumentos de derecho internacional público con distinto valor dentro de nuestro sistema de fuentes jurídicas (frente a los cuales el Estado peruano forma parte, se adhiere, ratifica o simplemente los asume de una manera referencial como auténticos institutos de soft $(a w)^{6} ;$ sino porque además

2 Allan Brewer-Carías, El modelo urbano de la ciudad colonial y su implantación en Hispanoamérica, Bogotá: Universidad del Externado, 2008, pp. 11-15.

3 Ibíd., p. 65.

4 Opinión brindada por el profesor de Historia Virreinal Rafael Sánchez-Concha y que puede ser revisada en el siguiente enlace: https://ucsp.edu.pe/saladeprensa/informa/elperu-no-fue-una-colonia-sino-un-reino-mas-dentro-del-imperio-iberico/.

5 Luis Pérez-Prat Durbán, "Observaciones sobre el derecho al patrimonio cultural como derecho humano", Periférica, n. ${ }^{\circ}$ 15, Cádiz: Universidad de Cádiz, 2014, p. 327.

6 Las convenciones Unesco ratificadas o adheridas por el Estado peruano pueden ser vistas en el siguiente enlace: http://www.unesco.org/eri/la/conventions_by_country.asp?cont $r=P E \&$ language $=S \&$ typeconv $=1$. Sin perjuicio que estos instrumentos son importantes 
nuestra Constitución ha reconocido claramente el principio de responsabilidad pública ${ }^{7}$ en cabeza y según cada específico orden competencial predicable a todas estas organizaciones del Poder Público (principalmente organizaciones administrativas), generando a continuación que el Legislador plantee una prioritaria obligación estatal por proteger y someter estas cosas a un régimen especial (artículo v de la Ley General del Patrimonio Cultural de la Nación).

Sin embargo, en un fundamento que comparte ese rasgo bíbrido que acompaña nuestro derecho administrativo de bienes culturales, la norma legal amplía el inicial protagonismo público hacia "los titulares de derechos sobre bienes integrantes del Patrimonio Cultural de la Nación y la ciudadanía en general". Estos últimos particulares, según indica el artículo v de la Ley General del Patrimonio Cultural de la Nación (LGPCN) "tienen la responsabilidad común de cumplir y vigilar el debido cumplimiento del régimen legal establecido en la presente ley". Esto mismo aparece repetido en el artículo 4 del Reglamento de la Ley General del Patrimonio Cultural de la Nación (RLGPCN), al indicarse que la "identificación, registro, inventario, declaración, protección, restauración, investigación, conservación, puesta en valor y difusión de los bienes culturales, y su restitución en los casos pertinentes es de interés social y necesidad pública e involucra a toda la ciudadanía [...] entidades [...] privadas".

Así, se ha expresado claramente que los bienes culturales que sean declarados como tales de manera definitiva o transitoria (por presunción razonable que necesita ser comprobada o justificada a posteriori) asumen la condición de

para el sistema de fuentes de los bienes culturales del país, debido al objeto del presente trabajo, también resulta importante tomar en cuenta al instrumento normativo Unesco denominado "Recomendación sobre el paisaje urbano histórico", de noviembre de 2011, la cual será citada frecuentemente en el texto principal. Finalmente, sobre el valor de este régimen supranacional puede revisarse el artículo de Luis Anguita Villanueva, "La protección jurídica de los bienes culturales en el derecho español", Ius et Praxis, n. ${ }^{\circ}$ 1, 2004, pp. 18-19.

7 En general, la responsabilidad debe ser entendida como el deber "de justificar la propia obligación con respecto a ciertos criterios o reglas, cuanto la concreta fiscalización de la misma $y$, en caso de un juicio negativo, el deber de soportar la correspondiente sanción". Véase Luis María Diez-Picaso, "Responsabilidad de los poderes públicos", en Enciclopedia jurídica básica, t. IV, Madrid: Cívitas, 1995, p. 5935. Ahora bien, el principio de responsabilidad pública derivado de la anterior noción se despliega en varios sectores de nuestra realidad (como la asistencia sanitaria, las prestaciones educativas, la propia gestión de bienes culturales y la asistencia y protección social) y se entiende como como obligaciones y exigencias recaídas sobre los poderes públicos, en pos de permitir el despliegue de una serie de derechos constitucionales, mediante la garantía de mínimos prestacionales y políticas públicas que puedan ser ejecutadas indistintamente por privados y organizaciones administrativas (por eso este principio encaja muy bien con la técnica prestacional del servicio esencial). Véase Juan Pemán Gavín, "El derecho constitucional a la protección de la salud. Una aproximación de conjunto a la vista de la experiencia de tres décadas de Constitución", Revista Aragonesa de Administración Pública, n. ${ }^{\circ}$ 34, Zaragoza: Instituto Aragonés de Administración Pública, 2009, pp. 46-47. 
"patrimonio cultural de la nación" y, a continuación, pasan a ser inmediatamente tutelados o "protegidos por el Estado", sin que para esto exista necesidad de un monopolio público respecto de la titularidad de estas cosas (ver el artículo 21 de la C.P.).

Ahora bien, el presente trabajo trata de explicar ciertas cuestiones de revalorización de la intervención municipal sobre los bienes culturales (muchos de ellos inmuebles radicados y que conforman el entramado vivo de las ciudades), a fin de plantear unos fundamentos distintos, que busquen superar ciertas taras de tratamiento y gestión innecesariamente centralistas creadas a razón de la reciente aparición del Ministerio de Cultura, el cual, de manera extraña, tiene habilitada la potestad exclusiva preceptuada en el literal b del artículo 7 de la Ley de Creación del Ministerio de Cultura (LCMC), respecto de "las acciones de declaración, investigación, protección, conservación, puesta en valor, promoción y difusión" de todo el patrimonio cultural de la nación ( $\sin$ importar las subcategorías y calidades distintas que existen dentro de esta noción amplia) $)^{8}$.

Por eso, además de entender el fundamental principio de responsabilidad pública, hace falta enlazar varias cuestiones e institutos que merecen ser explicados, a pesar que a priori aparentan ser lejanos del propósito del artículo (tales como el urbanismo, la descentralización administrativa y los conceptos propios del derecho de la organización). Así, pueden surgir los fundamentos y preguntas que merecen algún nivel de respuestas, siendo estos los siguientes:

a. El patrimonio cultural de la nación está compuesto por bienes materiales e inmateriales. En lo que importa por el objeto del presente trabajo, este se conforma en cuanto a los bienes materiales bajo una lista de numerus apertus preceptuada en el artículo 21 de la C.P., la cual se encuentra completamente abierta a los hallazgos y avances de la investigación tecnológica o las ciencias

8 El objeto central de esta colaboración es mostrar que los intentos reunificación centralista de las normas de creación y otras del Ministerio de Cultura no son las mejores respuestas para afrontar la compleja materia de los bienes culturales. Mas, si muchos de estos últimos tienen un innegable presencia, asentimiento, localización y aprovechamiento urbano o de cercanía a las urbes, conformando así elementos de potestades administrativas extremadamente compartidas que discurren entre el urbanismo, la gestión documentaria, la arqueología, la gestión puramente cultural, entre otras específicas. Por eso hace falta tomar en cuenta que la participación municipal es más que relevante, siendo esto un segundo objetivo específico de este trabajo que necesita ser explicado y analizado. Finalmente, para llegar a unir las piezas de las mencionadas finalidades hace falta definir muchos conceptos jurídico-administrativos, desde la propia noción de los bienes culturales, pasando luego por los modos de titularidad de estos, entre otros que resultan cercanos. En cualquier caso, un objetivo secundario de esta colaboración es también no olvidar el valor de los conceptos del derecho de la organización aplicables al caso concreto, tales como la subsidiariedad territorial y la propia descentralización administrativa, figuras que a veces parecen abiertamente olvidadas en aspectos sectoriales por el Legislador (o el Poder Ejecutivo actuando como Legislador delegado). 
pertinentes. En cualquier caso, este listado incluye de manera típica los bienes arqueológicos, construcciones, monumentos, lugares, documentos bibliográficos y/o archivísticos, bienes muebles artísticos o con valor testimonial, existiendo siempre un espacio abierto y de decisión discrecional para la inclusión de cualquier otro elemento material que presente una manifestación o valor de civilidad o singularidad ${ }^{9}$. Esta construcción del Constituyente ha sido luego desarrollada de una manera coherente por el Legislador a través de la inclusión de la fórmula italiana de los bienes culturales establecida en la LGPCN, tal como lo explicaremos en las siguientes líneas.

b. En segundo lugar, una cuestión que salta a la vista es que la mayoría de los bienes culturales recogidos en la lista tiene una sustancia y alcance manifiestamente municipal, pues se asientan, deberán conservarse y, finalmente, valorizarse siempre en un determinado territorio ${ }_{i}$ espacio sobre el cual pueden existir poblaciones y aparecerán una serie de intereses públicos de contenido básicamente local (locomoción y tránsito, urbanismo, ordenación territorial, ejercicios de libertad de empresa en sectores urbanos cualificados, los intereses públicos ligados a las actividades turísticas, la utilización cada vez más frecuente del subsuelo, entre otros). En cualquier caso, en este punto aparece un elemento fundamental de localización del bien cultural y la consecuente intervención protectora de la organización administrativa más cercana territorialmente, criterio que fue correctamente construido por la jurisprudencia comparada y que hace falta desarrollarlo en nuestro derecho ${ }^{10}$.

c. Por ende, y es algo que parece haberse olvidado en tiempos actuales (a partir de un Ministerio de Cultura sobredimensionado en esta materia y que no se sostiene, respeta y fomenta los prioritarios roles de las municipalidades), bajo la subsidiariedad territorial que nos rige en la cláusula del Estado descentralizado, las Administraciones públicas del Estado deben tener habilitadas potestades y ser competentes en una materia cuando estén en condiciones de responder y salvaguardar más rápida y eficazmente a un concreto interés público (en este caso, la protección y gestión de los bienes culturales localizados en ciudades). Si se quiere, el Legislador debería solo atribuir "las facultades necesarias para

9 Sobre este último concepto, resulta interesante revisar la Sentencia 17/1991 del Tribunal Constitucional español, por la cual se considera a estos actos discrecionales de inclusión como calificaciones formales de "bienes de interés cultural de los más relevantes del patrimonio histórico español [...] constituyendo un requisito para que puedan gozar de singular protección y tutela [...] y también por tanto para su defensa contra la exportación y la expoliación, pero lo es asimismo para la sumisión a un régimen singular derivado de su importancia cultural y que en su propia complejidad abarca medidas de estricta protección y defensa junto a otras que no lo son y tienen naturaleza jurídica variada". También, sobre esta misma materia, puede revisarse el trabajo de GERARDO Ruiz-RiCO, "El derecho andaluz del patrimonio histórico desde una perspectiva constitucional", Revista PH, n. ${ }^{\circ} 48$, Sevilla: Instituto Andaluz del Patrimonio Histórico, 2004.

10 Por todas, ver la Sentencia 103/1988 del Tribunal Constitucional Español. 
el gobierno y gestión de las materias que así reclame el interés común, manteniendo las demás en los niveles inferiores" ${ }^{\prime \prime 1}$.

d. Bajo este esquema conceptual, caben algunas preguntas frente a nuestra realidad actual: cpuede existir un Ministerio de Cultura que no se apoye en las competencias ejercitadas por las municipalidades del país sobre los bienes culturales?, ¿cuál debe ser el papel de la Administración pública del Estado respecto de los bienes culturales de titularidad pública que -por sobre todotienen una localización y ámbitos esencialmente municipales?, ¿se puede proteger, conservar y rentabilizar social y económicamente los bienes culturales de espaldas al orden competencial municipal?, y ino es necesario construir y aplicar materialmente "un deber genérico de colaboración interadministrativo en el ejercicio de sus funciones y competencias de conservación, difusión y fomento de patrimonio histórico (cultural), a través de relaciones de plena comunicación, cooperación y asistencia mutua"12?

e. A partir de lo planteado, cabe recordar que el Ministerio de Cultura peruano fue creado con un incorrecto afán omnicomprensivo, desde la introducción por el Legislador de una potestad ordenadora y de rectoría en el sector pertinente, que incluía la "formulación de planes, programas y proyectos nacionales en el ámbito de su sector para la promoción, defensa, protección, difusión y puesta en valor de las manifestaciones culturales" (literal b del artículo 5 de la LCMC), dándole a continuación la calidad de exclusiva y excluyente a esta macrofunción. Sin embargo, la distribución está mal ensamblada porque luego duplica las mismas potestades en el orden competencial compartido aplicado sobre las otras entidades descentralizadas. Así, con las municipalidades se dividen competencias (sin potestades exactas) ${ }^{13}$ de "defensa, conservación, promoción,

11 Antonio Abruña Puyol y Víctor Baca Oneto, Notas al curso de derecho administrativo, manuscrito, p. 54 .

12 Isabel González Ríos, "El catálogo y el inventario de bienes reconocidos como instrumentos de protección del patrimonio histórico andaluz. Cuestiones procedimentales y competencias municipales", Revista de Estudios de la Administración Local y Autonómica, n. ${ }^{\circ} 317$, Madrid: INAP, 2011, p. 49.

13 Las competencias compartidas son de las peores formas que tiene nuestro Legislador para supuestamente "repartir" las potestades administrativas o materias concretas entre los tres tipos de administraciones públicas territoriales que existen en nuestro derecho (las del Estado, los gobiernos regionales y las municipalidades). Esta forma de habilitación de funciones casi ritualmente sostenida en frases genéricas como las mostradas en el texto principal, genera un enorme caos en las relaciones entre el Estado y el resto de las organizaciones administrativas descentralizadas (y constitucionalmente autónomas), afectando el principio de unidad y - a la larga- la propia descentralización administrativa. En el ámbito cultural, vale recordar las certeras palabras del profesor Muñoz Machado en cuanto a la existencia de un "paralelismo pleno" en la distribución de competencia frente a esta importante materia en la realidad española, situación que en Perú se repite y amplifica, pero lo que es peor, termina con una permanente doble inacción de las administraciones públicas que supuestamente son competentes en -por ejemplo-patrimonio monumental 
difusión y puesta en valor de los monumentos integrantes del patrimonio cultural de la nación" (literal b del artículo 6 de la LCMC), dejándose de lado al resto de bienes culturales no monumentales y el gran marco que plantea los conjuntos bistóricos urbanos ${ }^{14}$.

En este punto, al menos desde este desorden, queda claro entonces que las municipalidades tendrían reconocidas y habilitadas de manera directa las potestades urbanísticas que impactan directamente en todos los inmuebles integrantes del patrimonio cultural de la nación (monumentos y otros predios sin esa condición), no solo por la atribución directa de la Ley Orgánica de Municipalidades (según lo explicaremos luego), sino porque esta cuestión se recalca expresamente en la $\mathrm{LCMC}^{15}$, quedando así el Ministerio de Cultura relegado a la práctica de una aparente competencia residual o subsidiaria en asuntos urbanísticos del patrimonio histórico y cultural del país ${ }^{16}$ (sin embargo, esta última competencia termina siendo mucho más intensa y definitiva que como inicialmente aparece regulada en la normatividad nacional, tal como lo veremos luego).

f. El artículo 21 de la C.P. plantea una pregunta, ¿qué es el patrimonio cultural de la nación? La contestación no es sencilla pues no existen rastros o fuentes en el derecho peruano que permitan darle un contenido y consistencia a esta noción. Todo esto, más allá de su permanente inclusión en las distintas normas infraconstitucionales (como la LGPCN y el RLGPCN) y ser usada como motivo esencial para la transformación de un bien común de titularidad pública o privada en uno de contenido cultural, produciéndose a continuación su inclusión en un verdadero régimen estatutario que obliga al propietario a "medidas y limitaciones" configuradas por el Legislador solo con el afán de salvaguardar los únicos propósitos de interés público de "conservación y protección" de la correspondiente cosa (artículo 3 de la LGPCN).

En cualquier caso, el patrimonio cultural de la nación es un concepto jurídico indeterminado, disperso, ligado a los cambios de los tiempos y basado en una lista variopinta de cosas materiales e inmateriales, públicas y privadas, descubiertas y no descubiertas, con presunciones a favor la integración de cosas en el concepto y con una cierta primacía pública (en el caso de los bienes culturales no descubiertos), que siempre deben tener un propietario al que se le obligue al

urbano. Véase Santiago Muñoz Machado, Derecho público de las comunidades autónomas, Madrid: Iustel, 2007, pp. 574 y ss.

14 Ver el preámbulo de la "Recomendación sobre el paisaje urbano histórico", aprobada por la UNESCO en noviembre de 2011.

15 La parte final del artículo 6 de la LCMC preceptúa que corresponde "ejercer a los gobiernos regionales y gobiernos locales, en su respectiva jurisdicción, aquellas funciones previstas en la Ley Orgánica de Gobiernos Regionales y la Ley Orgánica de Municipalidades. El ejercicio de dichas funciones debe guardar concordancia con las normas y políticas nacionales y sectoriales que dicte el Ministerio de Cultura".

Véase Gerardo Ruiz-Rico, óp. cit., pp. 70-71. 
citado régimen estatutario. Siendo este último el elemento caracterizador que lo diferencia de conceptos indeterminados de más reciente creación (como el patrimonio común de la bumanidad) ${ }^{17}$.

Por otro lado, otro conjunto de institutos que se encuentran íntimamente aparejado a los bienes que conforman el patrimonio cultural de la nación, no solo porque los últimos son los medios para su servicio y ejercicios plenos, sino además porque los primeros le dan carta de naturaleza a sus existencias en un régimen especial ${ }^{18}$, son una serie de facultades subjetivas ligadas al derecho constitucional a la participación "en la vida cultural de la Nación" (numeral 7 del artículo 2 de la C.P.), del cual se pueden extraer varias libertades y principalmente el llamado "derecho al patrimonio cultural" (declarado inicialmente por el artículo 15 del Pacto Internacional de los Derechos Económicos, Sociales y Culturales). Al respecto, este derecho constitucional tiene aparejado tres libertades individuales o de alcance colectivo, reconocidas implícitamente en nuestro derecho interno (y que aparece también preceptuada por la Convención del Faro de 2005 de la UNESCO):

a. En primer lugar, la participación en la vida cultural implica el derecho de toda persona, sea "sola, grupalmente, o en el seno de la comunidad a la que pertenece, a ejercer sus prácticas culturales" 1 .

b. La segunda libertad es la del "acceso a la vida cultural y, en particular el derecho de toda persona (sola, en asociación con otras o en comunidad) a conocer y comprender su propia cultura y la de otros, a través de la educación y la información y a recibir educación y capacitación de calidad con pleno respeto a su identidad cultural" 20 .

c. Por último, aparece la libertad para aportar en la vida cultural, que "se concreta en el derecho a contribuir en la creación de las manifestaciones culturales de la comunidad y en la formulación de las decisiones comunitarias que inciden sobre los derechos culturales"21. Facultad que incluso se ha reforzado en su contenido con la obligación recaída sobre el Ministerio de Cultura de potenciar el principio de participación ciudadana a través de la intervención colaborativa activa de "la población, las organizaciones de la sociedad civil y las comunidades en la gestión de protección, conservación y promoción de las

17 Véase Jacqueline Morand-Deviller, "Los bienes públicos y el derecho de propiedad", Revista de Estudios de la Administración Local y Autonómica, n. ${ }^{\circ}$ 317, Madrid: INAP, 2011, p. 16. Sobre el particular se ha afirmado que "sobre la base de la igualdad y la no discriminación el ejercicio a participar en la vida cultural requiere de la disponibilidad de bienes culturales para que sea posible su aprovechamiento; la accesibilidad, entendiendo por tal que los titulares del derecho puedan efectivamente disponer de oportunidades a su alcance-físico y financiero- para disfrutar de la vida cultural". Véase Luis Pérez-Prat Durbán, óp. cit., p. 332.

19 Ibíd

20 Ibíd.

21 Ibíd. 
expresiones artísticas, las industrias culturales y el patrimonio cultural material e inmaterial de la Nación, propiciando el fortalecimiento de la identidad nacional", tal como lo preceptúa el literal e del artículo 7 de LCMC.

Frente a estas libertades que deben ser preservadas y tuteladas por las Administraciones públicas, cabe preguntarse - de nuevo- si hacía falta crear un Ministerio de Cultura que tenga un papel casi monopolizador en la gestión de los bienes del patrimonio cultural de la nación ${ }^{22}$. Lo dicho, también abre el espacio para preguntarse si esta visión centralista y el rol actual del Ministerio de Cultura pueden abrir espacio para un mejor desenvolvimiento de las libertades de índole cultural antes detalladas, en todos los territorios de la República peruana; por ejemplo, si el Ministerio de Cultura es capaz de responder mediante verdaderas, localizadas y específicas políticas públicas destinadas a la potenciación y pleno auge del "acceso a la vida cultural" en ciudades y asentimientos distintos a la capital ${ }^{23}$. La duda planteada no es menor, si tomamos en cuenta que muchos de estos derechos subjetivos y libertades de los ciudadanos

22 Esta situación tiene su máxima expresión o muestra negativa en una desfachatada y antijurídica potestad nulificante del Ministerio de Cultura, la misma que aparece preceptuada en los siguientes términos: "Las ordenanzas, resoluciones, acuerdos y reglamentos emitidos por las municipalidades que se refieran a bienes culturales inmuebles, requieren opinión previa favorable, en caso contrario serán nulos de pleno derecho" (ver la primera parte del artículo 29 del RLGPCN). En este punto habría que recordar la diferencia entre actos administrativos y las normas legales o reglamentarias publicadas por las municipalidades, las últimas, aunque de carácter territorial acotado, tienen una naturaleza jurídica normativa (de innovación del conjunto del ordenamiento positivo). A esto habría que agregarle varias cuestiones sobre el valor de los actos administrativos (incluso aplicable a las opiniones técnicas de la Administración del Estado), el alcance de la nulidad de pleno derecho (de actos), la relación entre el Estado y las municipalidades, además de como la autonomía municipal puede ser asumida en tiempos actuales. En suma, esta disposición reglamentaria resume en buena medida la visión contraria a la cláusula del Estado descentralizado que acompaña a nuestro derecho de los bienes culturales (y de cultura en general).

23 Por ejemplo, para poder cubrir esta facultad el Ministerio de Cultura necesitaría tener un red de establecimientos públicos culturales en todos los territorios regionales del país, entendiendo que serían -siguiendo una noción material- un conjunto de centros interrelacionados donde se brinden servicios generales y organizados referidos a diversas manifestaciones culturales y de civilización (principalmente en artes plásticas, artes escénicas, arqueología literatura, investigación y recuperación de bienes culturales, etc.), permitiendo la satisfacción y disfrute de las necesidades colectivas propias del derecho a la participación en la vida cultural (y otras libertades propias de esta índole). En cualquier caso, esta estructura homogénea de establecimientos no existe, pues actualmente esta organización ministerial cuenta solo algunos proyectos culturales relevantes con puntuales establecimientos como el Naylamp-Lambayeque, el Complejo Arqueológico Chan Chan, el proyecto nacional del camino inca o Qhapaq Nam, entre otros, además de contar con oficinas desconcentradas en todo el país que cumplen como órganos de enlace y ejercitadores de algunas potestades técnicas de conservación u ordenación. Sobre la noción general de establecimiento público puede revisarse a GASPAR ARIÑO ORTIZ, "Sobre el concepto y significado institucional de la expresión establecimiento público", Documentación Administrativa, n. ${ }^{\circ}$ 155, Madrid: INAP, 1973 , pp. 18 y ss. 
aparejados tras la participación "en la vida cultural de la Nación" están ligados con los contenidos de los denominados derechos personales y civiles ${ }^{24}$, por ende la participación de la (más lejana) Administración del Estado debería ser la justa y necesaria (incluso porque así lo determina el mandato constitucional del principio de subsidiariedad territorial preceptuado implícitamente en el artículo 188 de la C.P. y expresamente reconocido en el literal $\mathrm{f}$ del artículo 4 de la LBD), permitiéndose, por el contrario, el despliegue de una más potente intervención de las municipalidades (claro, a partir de una asistencia técnica y jurídica decidida del Estado $)^{25}$.

Entonces, es claro que nuestro el régimen organizativo de las Administraciones públicas y el propio de bienes del patrimonio cultural de la nación necesita plantear y revalorizar el papel de las municipalidades en pos de cubrir buena parte y de mejor manera la gestión pública de estos últimos, sobre todo para aquellos ubicados fuera de la capital y que tienen la fundamental naturaleza urbana e inmueble (tan descuidados y olvidados por las organizaciones administrativas competentes). Esto último necesita no solo un nuevo orden competencial aplicable entre las Administraciones públicas territoriales involucradas, con potestades claramente habilitadas (según objetos exactos), sino un entendimiento cabal que vivimos en medio de la descentralización administrativa y esto implica desarrollar de manera pareja y equilibrada todo el país (más en un subsector como este, que permite alcanzar otros niveles de desarrollo personal de los ciudadanos y que, valgan verdades, se muestra como una notable

24 Véase Luis Castillo Córdova, Elementos de una teoría general de los derechos constitucionales, Lima: Ara, 2003, pp. 54-55.

25 Se ha dicho sobre la definición de este instituto (en versión territorial), que la "subsidiariedad se define como el principio según el cual las atribuciones y competencias deben ser ejercidas por el nivel de la administración mejor colocado para ejercerlas con racionalidad, eficacia y proximidad con los ciudadanos". Véase Salema D’Oliviera Martins, "El principio de subsidiariedad y la organización administrativa", Documentación Administrativa, n. ${ }^{\circ}$ 257-258, Madrid: INAP, 2000, p. 82. Esta misma posición sobre esta versión de la subsidiariedad ha sido planteada por el Tribunal Constitucional, indicándose que es "un principio íntimamente ligado con el tema descentralizador, y aplicable a la determinación correcta de competencias funcionales entre el órgano nacional, regional o autonómico. Sobre esta base, un principio institucional organizativo como es la subsidiariedad exige la atribución de competencias y responsabilidades públicas a las autoridades más próximas a los ciudadanos, que se encuentren en condiciones de ejercerlas, principio que enlaza de modo claro con la exigencia de que los intereses colectivos de ámbito estrictamente local sean expresados por quienes tienen legitimación para ello. Sin embargo, el principio de subsidiariedad no siempre se encuentra inserto en el texto [...] se trata muchas veces de orden doctrinario. Por lo tanto, y de inicio, este principio tiene por objeto garantizar una toma de decisión lo más cerca posible del ciudadano, comprobándose constantemente que la acción que debe emprenderse a escala nacional se justifica en relación con las posibilidades que ofrece el nivel regional o local". Véase Pleno del Tribunal Constitucional recaído en el Exp. 002-2005-PI/TC, del 18 de febrero de 2015, f.j. 52. 
oportunidad por potenciar el turismo, las novísimas industrias culturales y otras actividades económicas de interesante proyección).

Sin embargo, también hace falta que nuestro derecho administrativo especial de los bienes culturales y el propio derecho urbanístico, desde una reforma legislativa necesaria y urgente, se vuelvan más completos y sofisticados, permitiendo el ingreso de no pocos conceptos que nos hacen falta para permitir un mejor ejercicio de las pertinentes potestades (como, por ejemplo, el "paisaje urbano histórico", o la inclusión de una competencia exacta de "conservación, rehabilitación y rentabilización" aplicable sobre estos tipos de bienes, o de señalamiento exacto de unas obligaciones de contenidos similares aplicables sobre las propiedades privadas destinada a evitar los bienes ruinosos y la pérdida del valor cultural del objeto ${ }^{26}$ ).

\section{LOS DATOS DE UN RÉGIMEN HÍBRIDO Y POCO ANALIZADO. LOS FUNDAMENTOS ITALIANO Y ALEMÁN DEL DERECHO DE LOS BIENES CULTURALES PERUANOS}

El régimen peruano de los bienes culturales presenta una doble fundamentación en su estructura y base conceptual. Ambas raíces son de origen y propósitos distintos, pero con una gran tradición que bien pueden servirnos y ser un adecuado soporte jurídico para poder gestionar el importante patrimonio que nos ha sido legado por las generaciones pasadas. Por tanto, este derecho administrativo especial tiene una manifiesta naturaleza bibrida, en la que se entremezcla una italiana definición legal de bienes culturales similar a la propuesta en la famosa Comisión Reformadora Franceschini de 1964, en la que el notable M. S. Giannini tuvo una capital participación. Pero, además a partir de que la Constitución y el Legislador peruanos admiten que la titularidad de los bienes culturales puedan ser -indistintamente- pública o privada, se abre el espacio para la tesis alemana de los bienes particulares de interés público-cultural, sobre los cuales existiendo propiedad y dominio de un específico titular, aparece un verdadero estatuto jurídico que permite el despliegue de unas especiales potestades públicas de delimitación, sumado a una acentuación y detalle de una determinada fórmula de la función social de la propiedad (que viene establecida en genérico en el artículo 70 de la C.P.). De todo esto daremos cuenta a continuación.

\subsection{El fundamento italiano DE LOS BieNeS Culturales}

El 26 de abril del año 1964, el Parlamento italiano aprobó la Ley n. ${ }^{\circ}$ 310, por la cual trataba de buscar respuestas y construir un mejor derecho que otorgue

26 Véase Miguel García JimÉNEZ, El deber de conservación y rebabilitación de los centros bistóricos urbanos, manuscrito (tesis doctoral), pp. 33-36. 
una cobertura superior para la protección y gestión del inmenso patrimonio histórico, artístico y paisajístico de ese país. Para lograr la consecución de estos propósitos, esta norma dispuso la creación del grupo de trabajo denominado "D'indagine per la tutela e la valorizzazione del patrimonio storico, archeologico, artistico e del paesaggio" o simplemente Comisión Franceschini, bajo la que se asimiló como integrante al famoso e innovador M. S. Giannini.

Esta inclusión del profesor romano resultó decisiva para construir conceptos jurídicos sobre los bienes culturales muy trascendentes, vigentes hasta nuestros días y con un alcance insospechado (fundamentales para otros derechos como el nuestro, que no aparecen cercanos al área de influencia directa del derecho administrativo italiano). Y en este punto hay que ser claros, para producir esta reforma el profesor Giannini se alejó de las estructuras dogmáticas tradicionales del derecho italiano, por ejemplo, en los bienes culturales de titularidad privada eliminó el énfasis de definirlos desde "una vinculación pública [...] esto es, en el interés público de dichos bienes ${ }^{127}{ }_{i}$ para pasar a una visión mixta que mezcle la cosa material y el interés propio que el bien despierta ante los demás (la historicibilidad) ${ }^{28}$.

De las cuestiones más interesantes producidas por la Comisión Franceschini se encuentra la definición general adoptada sobre los bienes culturales, la cual se plantea en dos perspectivas, así "en sentido lato el concepto se define por el referimiento de los bienes a la historia de la civilización, lo que constituye $[\ldots]$ una connotación suficiente para identificarlo" ${ }^{\prime 29}$, pero no necesariamente puede ser el único elemento determinante para el derecho. A continuación, como indica Vaquer Caballería, el impulso de Giannini llevó a que se adopte un segundo criterio estricto de definición, en tanto, se le considera al bien cultural como un "testimonio material con valor de civilización, al que se le atribuye la calificación de noción jurídicamente válida, si bien su definición opera mediante el reenvío a disciplinas no jurídicas" ${ }^{\prime \prime}$. Ahora bien, este concepto se compone de dos grandes nociones ${ }^{31}$, por un lado, la cosa o receptáculo

27 Javier García Fernández, Estudios sobre el derecho del patrimonio bistórico, Madrid: Colegio de Registradores, 2008, p. 70.

28 Véase Juan Carlos González Zorzano, Límites de dominio de los bienes culturales muebles, manuscrito (tesis doctoral), p. 45. Aunque como bien reconoce este autor, los antecedentes de esta noción jurídica bien pueden encontrarse en la "Ley francesa de monumentos de 1830, o Ley Guizot, primera ley que recogía mecanismos para la conservación del patrimonio que se mantenía en manos privadas, aunque esta intervención lo era sólo de forma voluntaria [... . o el informe 'el culto moderno a los monumentos', de Alois Riegel, en 1903, que aboga [...] en la protección de los valores (ese es el valor histórico), que inspiró a otras legislaciones y que llevó a superar la propiedad privada como límite de protección". Véase la citada tesis doctoral en el pie de página número 65 (p. 47).

29 Marco Vaquer Caballería, "La protección jurídica del patrimonio cultural inmaterial", Revista Museos.es, n. ${ }^{\circ}$ 1, Madrid: Ministerio de Cultura, 2005, p. 90.

Ibíd.

31 Ibíd. 
material (que no supone que el bien cultural sea la cosa en sí misma ${ }^{32}$ ); y en segundo lugar, el valor cultural o inmaterial recogido en la cosa que se conecta a distintos tipos de intereses propios de la civilización (histórico, arqueológico, arquitectónico, religioso, etc.), lo cual es "expresión de la singularidad de cada época histórica [...] concepción plasmada en cada momento en las más diversas manifestaciones y representaciones, así como la valoración que las mismas han merecido a las posteriores generaciones" ${ }^{\prime \prime 3}$.

En cualquier caso, en esta definición prima el segundo elemento, pues el valor cultural manifestado en múltiples y distintos intereses, es la noción homogeneizadora y común de los bienes culturales (los cuales siempre serán de naturaleza inmaterial), siendo los citados intereses de carácter

público y objetivo (objetivo en cuanto referible a cualquier entidad del mundo externo en cuanto portadora de un valor cultural), dimanante del valor cultural que incorporan, en cuanto testimonios materiales dotados de un valor de civilización. En consecuencia, toda entidad del mundo exterior en que concurra aquel valor cultural es un bien cultural, valor cultural que, sin embargo, en cuanto noción histórica, resulta determinado por las distintas concepciones vigentes en cada momento ${ }^{34}$.

En adición, bajo este esquema conceptual, el concepto italiano de bienes culturales presenta dos notas caracterizadoras adicionales que recaen directamente sobre el objeto declarado como tal. Así, tenemos:

a. En primer lugar, el bien cultural, "independientemente de su titularidad pública o privada [...] debe ser accesible al uso público, al público disfrute de la sociedad, lo que legitima la intervención administrativa sobre los bienes cuya propiedad es privada" ${ }^{135}$. Es decir, esta característica abre el espacio para la construcción posterior de un verdadero estatuto de los bienes culturales, un régimen especial por la naturaleza de los objetos regulados, en el que se justifica una delimitación distinta para los de titularidad privada (para mantener los niveles de accesibilidad, mantenimiento integral, conservación y disfrute por parte de los terceros), y un componente adicional de construcción de redes de establecimientos y ensamble de proyectos para organizar, conservar y

32 Al respecto, debe distinguirse en el bien cultural "la cosa que constituye su soporte material, y con la cual no se identifica, de donde resulta la necesidad de diferenciar los derechos patrimoniales que recaen sobre la cosa, en cuanto objeto de valoración económica, y el derecho del Estado sobre el bien cultural en cuanto tal, derecho de contenido no patrimonial y siempre público". Véase Juan Manuel Alegre Ávila, Evolución y régimen jurídico del patrimonio bistórico. La configuración dogmática de la propiedad bistórica en la Ley 16/1985 de 25 de junio, del patrimonio bistórico español, Madrid: Ministerio de Cultura, 1994, p. 661.

Marco Vaquer Caballería, óp. cit., p. 90. 
rentabilizar de manera correcta los bienes culturales de titularidad pública (y los privados que puedan involucrarse).

b. Por otro lado, el bien cultural se clasifica y declara como tal solo a través de una única definición, que no puede ser disgregada o segmentada por leyes o reglamentos especiales. Así, como bien indica Ávila Alegre,

la noción unitaria que pretende superar las visiones sectoriales y parciales características de esta rama del ordenamiento jurídico (esto es, la existencia de una pluralidad de textos legislativos reguladores de conjuntos orgánicos de bienes: los de carácter histórico-artístico, las llamadas "bellezas naturales", los bienes arqueológicos, los bienes ambientales de carácter urbanístico, etc.), y que en definitiva sintetiza en una noción estrictamente jurídica el tratamiento de todos aquellos bienes de los que puede predicarse el ser testimonio o expresión del devenir histórico del hombre a lo largo del tiempo ${ }^{36}$.

Ahora bien, el bien cultural o bien integrante del patrimonio cultural de la nación (según la intercambialidad de nomenclaturas implantada por el artículo 3 del RLGPCN) es definido por el Legislador peruano como "toda manifestación del quehacer humano -material o inmaterial-que por su importancia, valor y significado paleontológico, arqueológico, arquitectónico, histórico, artístico, militar, social, antropológico, tradicional, religioso, etnológico, científico, tecnológico o intelectual, sea expresamente declarado como tal o sobre el que exista la presunción legal de serlo"(artículo II de la LGPCN).

En lo que nos interesa, como es claro, esta anterior definición normativa, además de englobar a los bienes inmateriales, tiene reconocido el doble componente de los bienes culturales italianos, apareciendo el elemento material o cosa (llamado "manifestación humana" en nuestro derecho positivo), al cual se le debe predicar un valor de civilidad o de interés cultural de distinta clase (determinadas manifestaciones que tengan o aparezcan revestidos con valores culturales diversos, más allá de su sola antigüedad, siendo una situación de bistoricidad que será definida por el "juicio técnico-valorativo de disciplinas científicas ajenas al mundo del derecho"37). Por lo dicho, nuestros bienes culturales aparecen claramente planteados desde una concepción funcional, en la que depende mucho la función y dimensión cultural que determinadas manifestaciones están llamadas a cumplir; cuestión que incluso se ve protegida por la citada presunción legal de inclusión o adelantamiento de la condición de bien cultural, frente a cosas materiales o inmateriales que tiene un nivel de historicidad o de pertenencia a la "época prehispánica, virreinal y republicana,

Ibíd. 
independientemente de su condición de propiedad pública o privada" (artículo III de la LGPCN).

Además, aparecen otros rasgos de los bienes culturales italianos claramente reconocidos en nuestro derecho, cuando, por ejemplo, se asume -implícitamente- la disgregación entre la cosa (en sí misma) y el valor cultural inmaterial que esta tiene (al cual se le otorga un carácter prioritario en la definición legal antes reseñada). En relación a este último componente es que nuestro Legislador ha considerado -de manera genérica- que los "derechos de la Nación sobre los bienes declarados patrimonio cultural de la nación son imprescriptibles" (artículo VI de la LGPCN). Así, se abre el espacio para dividir los derechos patrimoniales recaídos sobre la cosa o testimonio material (que podría ser practicados por un eventual titular privado), frente a aquellos otros "derechos de la $\mathrm{Na}$ ción" que serían extra commercium y esencialmente se referirían a la protección de los valores culturales intrínsecos (de la cosa) y la propia función social de los bienes culturales.

Por tanto, en este esquema conceptual, la materialidad del objeto se convertiría en un elemento de salvaguarda importante pero secundario, que siempre se despliega solo para tutelar el componente inmaterial, puesto que únicamente "no se protege los bienes culturales frente a las agresiones físicas [...] sino que también se protegen los valores propios de estos bienes y la función social que estos cumplen" ${ }^{\prime \prime 3}$.

En el mismo sentido, nuestra configuración de los bienes culturales determina la aparición de un régimen distinto y peculiar, que plantea un estatus singular para la función social aplicable sobre la propiedad de los bienes culturales, sea indistintamente esta última de titularidad pública o privada. La función social de los bienes integrantes del patrimonio cultural de la nación se "traduce en la imposición legal de una serie de obligaciones que disponen las normas que regulan esta materia" ${ }^{\prime \prime 2}$. De esto último, dada su cercanía e impacto directo sobre los bienes culturales de titularidad privada (o bienes privados de interés público-cultural), en el siguiente acápite daremos cuenta de todas las cuestiones pertinentes.

\subsection{El FUndAMENTO ALEMÁN DE LOS BieNeS CULTURALES PERUANOS}

El sustento alemán de los bienes culturales peruanos aparece en la propia Constitución, cuando esta reconoce expresamente que no existe un monopolio público o exclusiones de los particulares aplicables a las titularidades de estas cosas, permitiéndose la coexistencia de la propiedad pública y privada de

38 Carmen Terreros Andréu, "El expolio de patrimonio cultural: problemas de conceptualización jurídica", Revista electrónica del Patrimonio Histórico, n. ${ }^{\circ}$ 14, 2014, p. 78. Ibíd., p. 30. 
manera abierta y bajo un mismo régimen estatutario (artículo 21 de la C.P.). A continuación, el Legislador profundiza la convivencia de los dos tipos de titularidades, y empieza a diagramar una singularidad de reglas, pues todos estos bienes se encuentran "protegidos por el Estado y sujetos al régimen específico regulado en la presente ley" (artículo v de la LGPCN). Ahora bien, ya especificando las diferencias ontológicas de las cosas incluidas en el patrimonio cultural de la nación, el Legislador solo admite la existencia de titularidades privadas sobre los bienes culturales corpóreos (inmuebles o muebles), salvo alguna excepción de inmuebles que trataremos luego (basada en criterios de antigüedad y arqueológicos); preceptuando claramente que todos los inmateriales "por su naturaleza, pertenecen a la Nación; ninguna persona natural o jurídica puede arrogarse la propiedad de algún bien cultural inmaterial, siendo nula toda declaración en tal sentido, haya sido o no declarado como tal por la autoridad competente" (artículo 2 de la LGPCN).

Un segundo caso aparte y excluido de la titularidad privada son los bienes inmuebles integrantes del patrimonio cultural de la nación de carácter prebispánico, los cuales, por razones de marcada justificación arqueológica, son de exclusiva titularidad y gestión públicas, incluso existiendo esta forma de monopolio sobre un conjunto de bienes secundarios o complementarios a la cosa en sí misma, el cual se puede conformar por cualesquiera "partes integrantes y/o accesorias y sus componentes descubiertos o por descubrir" (numeral 6.1 de la LGPCN). Al respecto, el Legislador muestra un claro mandato conservacionista, incluso de presunción legal de tutela sobre los restos enterrados o no puestos a la luz, y de extensión territorial máxima sobre el correspondiente yacimiento arqueológico.

Más todavía, en este tipo de bienes corpóreos que deben tener una data comprobada anterior a $1532^{[40]}$, su régimen de limitaciones se amplifica hacia los predios públicos o privados donde se asienten, existiendo una obligatoria "unidad inmobiliaria" entre los primeros con los restos prehispánicos hallados, apareciendo así la obligación del privado o la organización administrativa propietaria de registrar el inmueble consolidado para "protegerlo y conservarlo, evitando su abandono, depredación y/o destrucción" (numeral 6.3 de la LGPCN). Sobre estos últimos deberes, aunque pueda discutirse la eficacia de los mismos (apareciendo la necesidad de innovar según lo explicaremos en la última parte de este trabajo), las actuaciones en contrario a estas limitaciones por parte del propietario, sea "por negligencia o dolo, acarrea responsabilidad administrativa, civil y penal" (numeral 6.3 de la LGPCN) ${ }^{41}$.

40 Este año es el que la mayoría de fuentes históricas muestran como el inicio del contacto y conquista del Imperio español sobre el Tahuantinsuyo Inca.

41 Extrañamente, para el caso de las organizaciones administrativas propietarias de inmuebles con restos pre-hispánicos, la LGPCN no ha incluido la atribución de responsabilidad disciplinaria en contra de los empleados públicos competentes, aunque ésta podría imputarse utilizando 
En todo caso, a partir de estos dos supuestos excepcionales, se admite explícitamente "la propiedad privada de bienes culturales muebles e inmuebles integrantes del patrimonio cultural de la nación" (artículo 4 de la LGPCN), permitiéndose que estas titularidades puedan desplegarse sobre las listas abiertas de bienes muebles e inmuebles preceptuadas en la norma legal peruana. Así, por ejemplo, un particular puede hacerse de la propiedad inmobiliaria "de edificios, obras de infraestructura, ambientes y conjuntos monumentales, centros históricos y demás construcciones, o evidencias materiales resultantes de la vida y actividad humana urbanos y/o rurales, aunque estén constituidos por bienes de diversa antigüedad o destino y tengan valor arqueológico, arquitectónico, histórico, religioso, etnológico, artístico, antropológico, paleontológico, tradicional, científico o tecnológico, su entorno paisajístico y los sumergidos en espacios acuáticos del territorio nacional" (numeral 1.1 de la LGPCN).

Como se notará de la anterior enumeración, de manera expansiva el Legislador permite que los privados puedan tener dominio de porciones históricas o de valor cultural de las ciudades, a partir de no excluir la posibilidad de que estos puedan ser titulares de conjuntos de monumentos y centros históricos, con lo cual, frente a estos bienes urbanos, se debe tener un especial cuidado, incluso con la necesidad de construir en el futuro inmediato un subrégimen dentro del general, para evitar la destrucción o disgregación de la correspondiente función social de estas posibles propiedades privadas. Esto último es un descuido normativo nacional que deberá llenarse pronto, quizás tomando como marco algunas de las disposiciones contenidas en la mencionada "Recomendación sobre el paisaje urbano histórico". En la actualidad, solo se cuenta con algunas regulaciones municipales y urbanísticas desconectadas una de otra, aprobadas por ciertas municipalidades peruanas (las cuales fundamentalmente tratan la intervención en inmuebles privados individualizados, pero no sobre estos objetos que involucran aspectos más complejos de entornos y unión con espacios públicos diversos) ${ }^{42}$.

Ahora bien, todas estas cuestiones permiten afirmar que en nuestro ordenamiento sectorial de cultura se ha admitido y positivizado -buena parte- la teoría alemana de los bienes privados de interés público, según la cual estas cosas son funcionalizadas más allá de su correspondiente titularidad, pues se encuentran dotadas de "una intrínseca y original cualidad para satisfacer un

algunos de los tipos infractores del vigente régimen del servicio civil (principalmente la negligencia profesional, siempre que con las conductas personal se hayan imputado un perjuicio económico, material o de gestión comprobado contra el interés público cultural o de protección de los bienes culturales de titularidad pública).

42 Como una muestra de lo afirmado en el párrafo principal, puede revisarse la normativa metropolitana del Centro Histórico de Lima. El conjunto de estos dispositivos puede encontrarse en el enlace: http://www.munlima.gob.pe/prolima/compendio-normas-delcentro-historico-de-lima. 
interés público. La Administración esta dotada de poderes a fin de asegurar su destino público [...]. El régimen jurídico del bien se articula alrededor de la exigencia de conservación y la satisfacción del interés público"43. Al menos estos conceptos se aplicarían de manera directa sobre los bienes culturales de titularidad privada, constituyendo verdaderos bienes muebles o inmuebles de interés público-cultural sobre los que cabe el "reconocimiento de una serie de facultades de uso y disfrute de naturaleza administrativa, a las que se unen los correlativos deberes de conservación, también de carácter administrativo, así como el desplazamiento o contracción de las facultades jurídico-civiles que corresponde al propietario en sentido lato" ${ }^{\prime 4}$.

Por eso, el artículo 6 de la LGPCN, a la par de reconocer y regular la propiedad privada de ciertos bienes corpóreos integrantes del patrimonio cultural de la nación, asume a continuación la implantación de "restricciones, limitaciones y obligaciones que dicha propiedad implica". Esto no es otra cosa que el planteamiento de un régimen estatuario de la titularidad privada de bienes culturales, en la que el contenido constitucional de este derecho subjetivo es muy singular y queda fuertemente limitado (por obligaciones de registro, conservación, de mantenimiento de la integridad física y valores inmateriales-culturales, inspección administrativa, restauración controlada, de ius aedificandi restringido, etc. ${ }^{45}$, además de delimitado por una función social acentuada y distinta (centrada en la necesidad de accesibilidad, uso, difusión y disfrute hacia el público interesado $)^{46}$. Todas estas cuestiones y la propia intervención administrativa (municipal y estatal), se asumen justificadas en "razón del interés público y de la conservación adecuada del bien".

Sin embargo, aunque este trabajo no verse sobre el análisis de las técnicas de delimitación y limitación de los bienes privados de interés público-cultural, la efectiva aplicación de todas estas o incluso en su sola instauración normativa (a partir del reconocimiento del fundamento alemán explicado), nunca debe obviarse que su objeto es un verdadero derecho de propiedad, reconocido desde la Constitución, con un contenido especial, pero siempre configurado a partir de "un ámbito de aprovechamiento privado exclusivo y excluyente, sujeto a

43 Marta Guerra López De Castro, "Los bienes culturales, noción y regulación en el derecho español, con especiales referencia al patrimonio de la Iglesia católica", Revista Chilena de Derecho, vol. 31, n. ${ }^{\circ}$ 2, Santiago: Pontificia Universidad de Chile, 2004, p. 314

44 Francisco Martínez VázQuez, "¿Qué es el dominio público?", Revista Themis, n. o 40, Lima: Asociación Civil Themis, 2000, p. 266

46 Solo así se puede entender la implantación de una función social singular basada -por ejemplo- en las obligaciones estatales de difusión por las que los "organismos competentes elaborarán estrategias, en coordinación con otras entidades del Estado, sector privado y organismos internacionales, con el objeto de promover y difundir la importancia y significado del patrimonio cultural de la nación como fundamento y expresión de nuestra identidad nacional" (ver el artículo 95 del RLGPCN). 
una función social, cuyo contenido radica en una genérica utilidad privada para su titular ${ }^{\prime \prime 4}$. Por ende, existe siempre la necesidad de re-equilibrar el ejercicio de potestades administrativas estatales o municipales, sean de limitación o de protección de la función social, tras una adecuada racionalización que impida la desconfiguración del derecho (hasta hacerlo irreconocible) o, lo que sería peor y completamente antijurídico, que en la práctica aparezca la imposibilidad de que esta forma de propiedad pueda ser ejercitada plenamente ${ }^{48}$.

Por la anterior cuestión es que la delimitación y limitaciones sobre la titularidad privada de interés cultural deberán ir acompañadas de selectivas fórmulas de la llamada actividad dispensadora de ayudas públicas ${ }^{49}$ (otorgadas a ciertos propietarios), las cuales deberán estar adaptadas para cumplir con algunos o todos los efectos obligacionales o de contenido económico que sean imposibles de soportar por el patrimonio de un determinado privado, necesitándose de la ejecución de subvenciones u otras imaginativas técnicas, sin cuya aparición y ejecución se pondría en riesgo o afectaría -en serio- la integridad material y los valores culturales inmanentes de los correspondientes bienes (principalmente inmobiliarios).

En este anterior punto, lo más importante es alcanzar unas cuotas mínimas de conservación y rentabilización social (y económica) del patrimonio histórico y cultural peruano, repartido entre las manos públicas y privadas, a fin de que la salvaguarda de este interés público sea efectiva, debiendo descartarse la sola aplicación policía administrativa cultural, de las facilistas políticas públicas declaracionistas y el mecánico traslado de las responsabilidades de estas cosas sobre los hombros privados (los que no son todos iguales para soportar las cargas, limitaciones y delimitaciones de esta propiedad tan peculiar). Todo esto, además, debe asumir un marco adecuado de colaboración entre las organizaciones administrativas competentes y los particulares de todo estilo ( $\sin$ esa unión nada se podrá hacer en serio), que se demuestre en técnicas complementarias a las señaladas ayudas públicas ${ }^{50}$.

Ahora bien, y a modo de cierre de este acápite (sin dejar de mencionar que nuestra doctrina tiene el deber de construir técnicas nuevas e innovadoras para esta materia), quiero mostrar un interesante ejemplo norteamericano de cómo repartir roles y responsabilidades en cuanto a bienes que originalmente eran

Héctor Santaella Quintero, "Notas sobre el concepto y garantía de la propiedad privada en la Constitución colombiana", Revista de Derecho Privado, n. ${ }^{\circ}$ 21, Bogotá: Universidad Externado de Colombia, 2011, p. 245. Ibíd., pp. 250-251.

49 Véase José Luis Martínez López-MuÑIz, "La actividad administrativa dispensadora de ayudas y recompensas: una alternativa conceptual al fomento, en la teoría de la administración pública", en Libro bomenaje al profesor José Luis Villar Palasí, Madrid: Cívitas, 1989, pp. $751-768$.

50 Véase la "Recomendación sobre el paisaje urbano histórico", aprobada por la UNESCO en noviembre de 2011 , p. 4. 
privados de interés cultural. Para esto seguiré lo explicado por la profesora Morand-Devill en los siguientes términos:

[la] separación entre usus y abusus, en beneficio del primer atributo, se encuentra también en otros sistemas de derecho. Así, podemos citar el régimen inteligente del National Trust, que ya cuenta con más de un siglo y que ha permitido salvaguardar el interés de los propietarios de monumentos y de jardines históricos, que no contaban con la capacidad de asumir el mantenimiento de los mismos por sí solos (conservan su uso y disfrute y se preserva su derecho de sucesión) y el interés general. La propiedad de los bienes se transfiere al National Trust, que garantiza su conservación y puesta en valor, si bien no gozan de la libre disposición de los mismos, dado que son bienes a los que se aplica el concepto de inalienabilidad ${ }^{51}$.

\section{EL ROL MUNICIPAL PRINCIPAL. LOS BIENES INMUEBLES CULTURALES DE TITULARIDAD MUNICIPAL Y LA INTERVENCIÓN MUNICIPAL SOBRE LA PROPIEDAD PRIVADA DE INTERÉS PÚBLICO-CULTURAL}

Como hemos podido plantear en anteriores líneas, el Legislador peruano tiene una serie de habilitaciones por las que otorga un rol protagónico y de tendencia casi excluyente a la Administración del Estado en el tratamiento y gestión de los bienes integrantes del patrimonio cultural de la nación, por encima del casi oscuro (e incompleto) papel de las entidades descentralizadas (principalmente las municipalidades). Vale indicar que las primeras competencias y responsabilidades no se condicen con las naturalezas heterogéneas de las cosas que componen la anterior noción, además de oponerse al propio contenido del principio de subsidiariedad territorial y los derechos constitucionales de los ciudadanos involucrados tras el despliegue de los bienes culturales.

Por eso, en este punto se necesita algo más que un Ministerio de Cultura y organismos públicos adscritos al primero, concentrados - principalmente- en algunas materias culturales y determinadas técnicas de policía administrati$\mathrm{va}$, a los cuales poco les importa tomar en cuenta y potenciar las relaciones intersubjetivas con las organizaciones administrativas de corte territorial. Por el contrario, ante esta situación hace falta compartir roles y revalorizar la intervención municipal de cara a los bienes culturales, todo esto debido a una sencilla razón que ya la habíamos adelantado: "los conjuntos históricos urbanos están entre las manifestaciones más abundantes y diversas en el patrimonio cultural común, que se ha forjado generación tras generación y constituye un testimonio crucial del quehacer y las aspiraciones del género humano a través del tiempo y el espacio" ${ }^{152}$.

52 Ver el preámbulo de la "Recomendación sobre el paisaje urbano histórico". 
Ahora bien, más allá de su tipología, las municipalidades peruanas en la actualidad se encuentran confinadas a cuatro grandes ámbitos de intervención:

a. En la materia de la organización y uso del suelo, se hace referencia al patrimonio bistórico, cultural y paisajístico, sin indicarse detalles o actuaciones específicas (numeral 1.9 del artículo 73 de la Ley Orgánica de Municipalidades), para a continuación habilitar a las municipalidades con dos potestades ejecutivas, una propia del régimen de gestión de bienes culturales centrada en la "protección y difusión del patrimonio cultural de la nación, dentro de su jurisdicción"; y en segundo lugar, se otorga una potestad compartida para la gestión monumentalista destinada a "la defensa y conservación de los monumentos arqueológicos, históricos y artísticos, colaborando con los organismos regionales y nacionales competentes para su identificación, registro, control, conservación y restauración" (numeral 12 del artículo 82 de la Ley Orgánica de Municipalidades). En este ámbito es donde se ubicaría las más importantes actuaciones de las organizaciones locales sobre los bienes culturales inmobiliarios de titularidad municipal (parques, monumentos, buena parte de los centros históricos y/o cascos urbanos con contenido cultural, paisajes urbanos, etc.)

b. Un segundo rubro de contenido prestacional es la creación, organización y sostenimiento de establecimientos culturales de titularidad municipal en toda la jurisdicción territorial en la que la municipalidad correspondiente sea competente, tales como "centros culturales, bibliotecas, teatros y talleres de arte", entre otros (numeral 11 del artículo 82 de la Ley Orgánica de Municipalidades). En este punto, considero que implícitamente el Legislador reconoce la necesidad de tener verdaderas redes de establecimientos ${ }^{53}$, a fin de brindar las prestaciones con acceso, calidad y regularidad homogéneos en todos los rincones del distrito o provincia pertinentes. Solo así se podría cumplir con la promoción de "actividades culturales diversas" (11 del artículo 82 de la Ley Orgánica de Municipalidades).

c. Un tercer rubro es la planificación urbana y de ordenación territorial, concretada en la realización y aplicación de varios instrumentos tales como el plan de desarrollo urbano, el plan de desarrollo rural, el esquema de zonificación de áreas urbanas, el plan de desarrollo de asentamientos humanos y demás planes específicos, todos nacidos desde el instrumento matriz llamado Plan de Acondicionamiento Territorial de la Provincia (numerales 1.1 y 1.2 del artículo 79 de la Ley Orgánica de Municipalidades). Debe decirse que estas técnicas planificatorias constituyen elementos desaprovechados en la actualidad (muchas veces por falta de pericia de la función pública municipal),

53 Es decir que estos establecimientos culturales de titularidad municipal supongan la "ordenación de las infraestructuras de una determinada manera, caracterizándose, precisamente, por la organización, esto es por la forma en que procede enlazar los distintos puntos de la red al servicio de una finalidad concreta". Véase GASPAR AriÑo OrTIZ et al., Las telecomunicaciones por cable, Madrid: Marcial Pons, 1996, p. 26. 
debido a que su correcta ejecución supone la instauración de efectos generales de protección.

Por otro lado, como puede observarse, en el ordenamiento nacional no existe un instrumento específico para la identificación, tutela, gestión y conexión con aspectos urbanísticos de los bienes culturales asentados en un concreto territorio provincial o distrital (principalmente inmobiliarios); con lo cual se ha venido asumiendo que los cascos y centros históricos, además de otras porciones de este tipo de patrimonio cultural urbano, se encuentran supeditados al ejercicio de la potestad de planificación que tenga cada municipalidad (mediante los concejos municipales a través de la previa aprobación de ordenanzas).

d. Un último ámbito en el que la intervención municipal se ha tornado prioritaria es en la ejecución de parte del régimen de limitaciones y delimitaciones de la propiedad inmobiliaria privada de interés público-cultural, con especial énfasis sobre aquellos bienes culturales ubicados en urbes. Todo esto, a partir de reconocerse que las municipalidades tienen habilitadas las potestades de gestión y disciplina urbanísticas ${ }^{54}$ referidas al otorgamiento de "licencias de construcción, remodelación o demolición" (numeral 1.4.1 del artículo 79 de la Ley Orgánica de Municipalidades); además de la creación de normatividad, regulación, fiscalización y otorgamiento de autorizaciones, derechos y licencias para las habilitaciones urbanas y la construcción, remodelación o demolición de inmuebles y declaratorias de fábrica (numerales 3.6.1 y 3.6.2 de la Ley Orgánica de Municipalidades, referidos principalmente al control previo y posterior de la actividad edificatoria).

Aunque estas últimas potestades municipales parecen potentes desde la habilitación establecida en la Ley Orgánica de Municipalidades (LOM), sin embargo en la práctica y a partir de su relación con el ordenamiento nacional de cultura, bajo el peso de la realidad aparecen con algunas injustificadas restricciones, como, por ejemplo, la necesidad de que el otorgamiento de las licencias de edificación o incluso cualquier forma distinta de intervención sobre el predio (hasta las propias de protección y conservación), contengan de manera antelada unas específicas opiniones ${ }^{55}$ o autorizaciones vinculantes emitidas por un órgano especializado del Ministerio de Cultura (Dirección

54 Véase Fernando López-Ramón, Lecciones de derecho urbanístico aragonés, Zaragoza: ThomsonReuters, 2011, pp. 134 y ss.

55 En el derecho administrativo peruano existen muchas técnicas de policía administrativa que se acercan al régimen de las autorizaciones, a pesar que no tienen el nomen adecuado (se les llama registros, opiniones, dictámenes, etc.). Por eso, más allá de la nomenclatura, siempre el operador debe fijarse en el contenido conceptual y efectos que preceptúan las normas al reconocer el correspondiente instituto. En el caso, de las citadas opiniones para la intervención de predios con valor monumental, estas son técnicas de control previo que revisan las legalidad cultural y aspectos técnicos de la futura actuación privada, con lo cual, se asemejan a una auténtica autorización administrativa (en su versión clásica). 
de Patrimonio Histórico Inmobiliaria ${ }^{56}$, las cuales permiten el ejercicio de las correspondientes facultades de la propiedad y además contienen un efecto "nulificante" sobre la mencionada autorización municipal, si es que la misma no aparece otorgada favorable y previamente al interesado (por ende, son consideradas como requisitos necesarios para la práctica de distintas formas del ius aedificandi por parte de titulares privados de bienes inmobiliarios declarados como parte del patrimonio cultural de la nación).

La anterior situación plantea una serie de cargas procedimentales adicionales sobre los administrados. De manera directa y más aguda para los particulares ubicados fuera de la capital, quienes deberán iniciar y continuar la tramitación de estas opiniones o autorizaciones en las oficinas desconcentradas de las capitales departamentales, si es que claro tienen la suerte que en su lugar de residencia se encuentre alguna cerca. Además, que la permanencia y los efectos de la opinión también condiciona el otorgamiento y ejecución de la licencia de edificación, apareciendo así ambos actos administrativos alejados de la idea de protecciones integrales y conjuntas de intereses públicos involucrados (el urbanísticos y el cultural).

Es más, la situación de separación entre los dos intereses públicos que se funden en el bien cultural inmobiliario se ha profundizado, no solo por el desprecio o abandono del Legislador de las potestades planificatorias (que deberían abordar lo urbano y culturales de manera conjunta ${ }^{57}$, sino porque no se toma en cuenta la necesidad de integración de estos bienes inmobiliarios en varios espacios urbanos, apareciendo los famosos cascos, centros históricos o ámbitos urbanos que merecen una tutela y potenciación (municipal) diferentes; siendo además sitios de las ciudades en los que se deben ejercer varios derechos civiles (son finalmente bienes al servicio de las personas, no al revés, como a veces se lee implícitamente en los fundamentos de varios actos del ordenamiento de cultura).

Incluso, para ir en el sentido contrario al que considero deberíamos enrumbarnos, una reciente reforma legislativa refuerza la potestad sancionadora del Ministerio de Cultura sin conexiones con los diferentes regímenes sancionadores municipales existentes ( $\mathrm{y}$, como no, de ciertos principios sancionadores comunes), permitiéndose la imposición de puniciones que -a priori-aparecen más cercanas a los necesarios despliegues de las competencias locales (realmente las municipalidades son las únicas organizaciones administrativas que

56 Los procedimientos concretos de estas materias a cargo de este órgano administrativo pueden ser revisados en los numerales 2, 3, 4 y 5 del Texto Único de Procedimientos Administrativos del Ministerio de Cultura. Este instrumento de gestión puede ser visto a través del siguiente enlace: http://www.cultura.gob.pe/sites/default/files/atencionciudadano/tablaarchivos/06/formatotupadelmcconsolidadofinalaprobado04-02-2015.pdf.

57 Véase Juan Manuel Alegre Ávila, "El ordenamiento estatal del patrimonio histórico español...", óp. cit., p. 609 
podrían descubrir estas formas de infracciones administrativas, a partir de la práctica de las inspecciones urbanas $)^{58}$.

Por otro lado, y siguiendo el anterior supuesto, en la actualidad se condiciona de sobremanera el ejercicio de la propiedad privada de interés públicocultural, existiendo muchas más cargas que las exigidas por la naturaleza de estas cosas y sin asumir la propia cláusula del Estado descentralizado en la que vivimos. Estas limitaciones parecen alejadas de los principios antiformalistas y la eficacia en la salvaguarda de los mencionados intereses públicos, que tienen por objeto al mismo bien corpóreo.

Por eso, en estos casos hace falta repensar el orden competencial de los dos tipos de entidades administrativas territoriales involucradas y eliminar esta perspectiva atrasada de segmentación entre la materia urbanística y orden cultural de la propiedad inmobiliaria ${ }^{59}$, siendo posible ir a soluciones como la implantación de los denominados procedimientos complejos ${ }^{60}$, hasta la progresiva municipalización del control previo del valor cultural de los bienes inmobiliarios de titularidad privada (contando para esto con los decisivos empujes y asistencia técnica del Ministerio de Cultura a favor de las organizaciones locales del país $)^{61}$.

58 La reciente reforma del literal $\mathrm{f}$ del numeral 49.1 de la LGPCN, promovida por el artículo 1 del Decreto Legislativo 1255, preceptúa que el Ministerio de Cultura tiene potestad sancionadora para imponer "multa o demolición de intervención u obra pública o privada ejecutada en inmuebles integrantes del patrimonio cultural de la Nación cuando se realiza sin contar con la autorización del Ministerio de Cultura o cuando contando con tal autorización se comprueba que la obra se ejecuta incumpliéndose lo aprobado o autorizado por el Ministerio de Cultura". Ante esto vale aclarar, que muchas municipalidades peruanas frente a construcciones irregulares que no cuenten con licencia de edificación o no apliquen exactamente los parámetros e indicaciones aprobadas mediante esta, someten a los correspondientes particulares a las mismas sanciones administrativas.

59 Véase Juan Manuel Alegre Ávila, "El ordenamiento estatal del patrimonio histórico español...", óp. cit., p. 607.

60 La figura de los procedimientos complejos o integrados que podrían construirse para el otorgamiento al propietario privado de una sola autorización con efectos edificatorios, urbanísticos y culturales, debe ser entendido como como "un procedimiento de procedimientos. En el procedimiento complejo, en efecto, funcionan como eslabones de la cadena procesal distintos procedimientos administrativos que, considerados aisladamente, carecen de eficacia bastante para conseguir un determinado fin público, el cual solo puede lograrse mediante la concatenación o integración de esos distintos procedimientos". Véase FrANCISCO González Navarro, "Procedimiento administrativo común, procedimientos triangulares y procedimientos complejos", Revista de Estudios de la Administración Local y Autonómica, n. ${ }^{\circ} 211$, Madrid: INAP, 1981, p. 440

61 Véase Isabel GonZález Ríos, óp. cit., p. 49. 


\section{A MODO DE CONCLUSIÓN. REFLEXIONES FINALES QUE PODRÍAN INICIAR LA RECONSTRUCCIÓN DE UN RÉGIMEN DE BIENES MUNICIPALES CULTURALES CON ALCANCES MÁS REALISTAS Y DE CERCANÍA AL INTERÉS PÚBLICO}

Lo fundamentado y explicado a lo largo de esta colaboración, nos ha llevado por un recuento de las corrientes doctrinales que impactaron y son actualmente relevantes para nuestro derecho de los bienes culturales, sumándose el planteamiento de los correspondientes institutos que resultan esenciales para conformar y diagramar su contenido (el principio de responsabilidad pública, la descentralización administrativa, la convivencia de organizaciones administrativas, etc.); pero en varios partes del trabajo siempre ha ido apareciendo un claro déficit: el estatismo en la gestión de los bienes culturales que se traduce en una suerte de inmediato rol protagónico y casi excluyente del novísimo Ministerio de Cultura, por encima de otras entidades administrativas descentralizadas y también competentes (entre las cuales resalta las antiguas y pre-republicanas municipalidades). Además de un desequilibrio frente al papel desempeñado por los privados implicados o relacionados con estas cosas (a los cuales se los deja en una posición casi de subordinados y destinados a recibir solo limitaciones y formas de delimitación de sus respectivos derechos de propiedad de interés público-cultural, sin que se planteen mayores formas de colaboración o de prestación de apoyo).

Ante estas cuestiones, hace falta cambios normativos que permitan la introducción de figuras nueva, el desarrollo de contenidos de aquellos institutos que se encuentran solo mencionados en la actuales normas sectoriales, el replanteamiento del orden competencial entre las Administraciones públicas competentes (concentrando el esfuerzo en ordenar las relaciones y potestades sobre la materia entre el Ministerio de Cultura y las municipalidades), para finalmente producir las conexiones efectivas entre los regímenes involucrados (municipal, urbanístico, ambiental y de cultura).

En cualquier cosa, todas estas consideraciones me permiten concluir con las siguientes cuestiones, las cuales buscar ser un punto de inicio para construir un mejor derecho administrativo de los bienes culturales:

a. Tenemos un régimen de bienes culturales de fuertes tradiciones jurídicas y con bases interesantes, principios relevantes y con un nivel orden interno, pero todavía falto de institutos muy importantes. Por ende, es incompleto o poco sofisticado, incapaz de afrontar con eficacia la protección del interés cultural en tiempos de descentralización administrativa, de la lucha obligatoria por un urbanismo sostenible en nuestras urbes y por la necesidad de potenciar en paralelo otros intereses públicos conectados con el primero (de algunos ya dimos cuenta a lo largo del trabajo). Aunque la lista de mejoras jurídicas puede 
ser larga, creo que sería bueno empezar por algunas puntuales de diferente índole, tal como daremos cuenta en las siguientes líneas.

b. En concordancia con lo dicho, creo que es urgente introducir en nuestro derecho positivo el concepto de redes de establecimientos de interés cultural de titularidad pública, noción que correctamente utilizada desde el ordenamiento nacional permitirá la homogeneización en el acceso y ejecución de prestaciones pertinentes a favor de los ciudadanos (pudiendo existir los estatales del Ministerio de Cultura, pero con una clara tendencia a que estos establecimientos aparezcan de forma prioritaria en el ámbito municipal). La única manera de no concentrar la práctica de la vida cultural solo en determinados territorios (favorecidos) y que mejor aún los bienes inmateriales y materiales muebles tengan algún nivel de visibilidad, explotación y rentabilización económica y social ${ }^{62}$, es que existan redes de estas infraestructuras repartidas en todo el país, correctamente sostenidas con fondos públicos bien invertidos y con una clara tendencia a ser un aparato prestacional abierto a todos los interesados.

c. Por otro lado, si los bienes inmobiliarios culturales son de los más relevantes y mayor número, ya va siendo hora de desarrollar el concepto de patrimonio paisajístico que aparece preceptuado en el numeral 1.9 del artículo 73 de la LOM. Hasta ahora solo se hace mera mención o referencia en el ordenamiento estatal y algunos regímenes municipales más avanzados (en particular, aquellos que intentan regular centros históricos con un relevante interés paisajístico), sin embargo, ni existe un concepto positivizado para este bien jurídico ${ }^{63}$, ni menos aparecen las tipologías de esta noción aplicables sobre los bienes culturales (como el paisaje urbano ${ }^{64}$ o el llamado paisaje urbano histórico ${ }^{65}$ ), ni tampoco aparecen los contenidos que surgen alrededor del paisaje (como los derechos aparejados, sean estos colectivos e individuales, las técnicas aplicables para

62 Véase Julián Pimiento EcheverRI, Derecho administrativo de bienes. Los bienes públicos: bistoria, clasificación, régimen jurídico, Bogotá: Universidad del Externado, 2015, pp. 26-27.

63 Véase Diana Carolina Zuluaga Varón, El derecho al paisaje en Colombia. Consideraciones para la definición de su contenido, alcance y límites, Bogotá: Universidad del Externado, 2015, p. 84 y ss.

64 Entre todas las revisadas, me pareció relevante y bien ensamblada la definición de paisaje urbano que aparece en la ordenanza catalana de los usos del paisaje urbano de la ciudad de Barcelina, aprobada mediante Acuerdo del Consejo Plenario de 26-3-1999. En la exposición de motivos de esta norma municipal se le define como un concepto medioambiental con incidencia urbanística, debiendo distinguirse ambas perspectivas que "reside, fundamentalmente, en el hecho de que los límites derivados de las normas urbanísticas a través de los planos responden a una visión anticipada de la ciudad, mientras que los límites impuestos por las normas ambientales del paisaje urbano se localizan en la realidad física de la ciudad como un resultado de su historia, sin que eso implique, no obstante, su estancamiento".

65 El paisaje urbano histórico es definido como la "zona urbana resultante de una estratificación histórica de valores y atributos culturales y naturales, lo que trasciende la noción de conjunto o centro histórico para abarcar el contexto urbano general y su entorno geográfico". Véase el numeral 8 de la "Recomendación sobre el paisaje urbano histórico". 
su conservación, protección, gestión y ordenación ${ }^{66}$, las percepciones que deben existir sobre el paisaje sea visual, estética, de culturalidad, seguridad y protección de personas, los elementos que lo conforman, las conexiones con los intereses públicos ambientales, urbanísticos y de sostenibilidad de las ciudades, entre otros).

d. Por último, un punto que habría que recordar a los operadores que ejecutan la legislación sectorial de cultura, es la máxima implantada por el artículo 1 de nuestra C.P.: "La defensa de la persona humana y el respeto de su dignidad son el fin supremo de la sociedad y del Estado". Esta misma traducida sobre la aplicación e interpretación del régimen de bienes culturales, implica siempre aceptar, promover y potenciar al máximo el ejercicio de los derechos de las personas involucradas. Por ende, estas normas no tienen por propósito de interés público, la protección o rentabilización social o económica de la cosa por la cosa misma (bajo erradas perspectivas economicistas, de mero inmovilismo o el puro conservacionismo); muy por el contrario, se necesitan que estos bienes culturales sean útiles y medios verdaderos para el ejercicio de no pocos derechos subjetivos (la vivienda, la libertad de empresa, el acceso a una vida cultural, el proyecto de vida, la propia participación cultural entre otros). Por tanto, los bienes culturales existen solo y para las personas.

\section{BIBLIOGRAFÍA}

Abruña Puyol, Antonio y Víctor Baca Oneto. Notas al curso de derecho administrativo, manuscrito.

Alegre Ávila, Juan Manuel. Evolución y régimen jurídico del patrimonio bistórico. La configuración dogmática de la propiedad bistórica en la Ley 16/1985 de 25 de junio, del patrimonio bistórico español, Madrid: Ministerio de Cultura, 1994.

Alegre Ávila, Juan Manuel. "El ordenamiento estatal del Patrimonio Histórico Español: Principios y bases de su régimen jurídico", Revista de Estudios de la Administración Local, n. ${ }^{\circ}$ 255-256, 2001-2003.

Anguita Villanueva, Luis. "La protección jurídica de los bienes culturales en el derecho español", Ius et Praxis, n. ${ }^{\circ}$ 1, Talca: Universidad de Talca, 2004.

Ariño Ortiz, GaSPar. "Sobre el concepto y significado institucional de la expresión establecimiento público", Documentación Administrativa, n. ${ }^{\circ}$ 155, Madrid: INAP, 1973.

Ariño Ortiz, Gaspar et al. Las telecomunicaciones por cable, Madrid: Marcial Pons, 1996. 
Brewer-Carías, Allan. El modelo urbano de la ciudad colonial y su implantación en Hispanoamérica, Bogotá: Universidad del Externado, 2008.

Castillo Córdova, Luis. Elementos de una teoría general de los derechos constitucionales, Lima: Ara, 2003

D'oliviera Martins, Salema. "El principio de subsidiariedad y la organización administrativa", Documentación Administrativa, n. ${ }^{\circ}$ 257-258, Madrid: INAP, 2000.

Diez-Picaso, Luis María. "Responsabilidad de los poderes públicos", en Enciclopedia jurídica básica, t. IV, Madrid: Cívitas, 1995.

García Fernández, JaVier. Estudios sobre el derecho del patrimonio bistórico, Madrid: Colegio de Registradores, 2008.

García Jiménez, Miguel. El deber de conservación y rebabilitación de los centros bistóricos urbanos, manuscrito (tesis doctoral).

González Navarro, Francisco. "Procedimiento administrativo común, procedimientos triangulares y procedimientos complejos", Revista de Estudios de la Administración Local y Autonómica, n. ${ }^{\circ}$ 211, Madrid: INAP, 1981.

GonZÁLEZ Ríos, ISABEL. "El catálogo y el inventario de bienes reconocidos como instrumentos de protección del patrimonio histórico andaluz. Cuestiones procedimentales y competencias municipales", Revista de Estudios de la Administración Local y Autonómica, n. ${ }^{\circ}$ 317, Madrid: INAP, 2011.

González Zorzano, Juan Carlos. Límites de dominio de los bienes culturales muebles, manuscrito (tesis doctoral).

Guerra López de Castro, Marta. "Los bienes culturales, noción y regulación en el derecho español, con especiales referencia al patrimonio de la Iglesia católica", Revista Chilena de Derecho, vol. 31, n. ${ }^{\circ}$ 2, Santiago: Pontificia Universidad de Chile, 2004.

LÓPEZ-RAMÓN, FERNANDO. Lecciones de derecho urbanístico aragonés, Zaragoza: ThomsonReuters, 2011.

Martínez López-MuÑIZ, JosÉ Luis. "La actividad administrativa dispensadora de ayudas y recompensas: una alternativa conceptual al fomento, en la teoría de la administración pública", en Libro bomenaje al profesor José Luis Villar Palasí, Madrid: Cívitas, 1989.

Martínez VázQuez, Francisco. "¿Qué es el dominio público?", Revista Themis, n. ${ }^{\text {4 }} 40$, Lima: Asociación Civil Themis, 2000.

Morand-Deviller, Jacqueline. "Los bienes públicos y el derecho de propiedad", Revista de Estudios de la Administración Local y Autonómica, n. ${ }^{\circ}$ 317, Madrid: INAP, 2011. 
Muñoz Machado, Santiago. Derecho público de las comunidades autónomas, Madrid: Iustel, 2007.

Pemán Gavín, Juan. "El derecho constitucional a la protección de la salud. Una aproximación de conjunto a la vista de la experiencia de tres décadas de Constitución", Revista Aragonesa de Administración Pública, n. ${ }^{\circ} 34$, Zaragoza: Instituto Aragonés de Administración Pública, 2009.

Pérez-Prat Durbán, Luis. "Observaciones sobre el derecho al patrimonio cultural como derecho humano", Periférica, n. ${ }^{\circ}$ 15, Cádiz: Universidad de Cádiz, 2014.

Pimiento Echeverri, Julián. Derecho administrativo de bienes. Los bienes públicos: bistoria, clasificación, régimen jurídico, Bogotá: Universidad del Externado, 2015.

Ruiz-Rico, Gerardo. "El derecho andaluz del patrimonio histórico desde una perspectiva constitucional", Revista PH, n. ${ }^{\circ} 48$, Sevilla: Instituto Andaluz del Patrimonio Histórico, 2004.

Santaella Quintero, Héctor. "Notas sobre el concepto y garantía de la propiedad privada en la Constitución colombiana", Revista de Derecho Privado, n. ${ }^{\circ} 21$, Bogotá: Universidad Externado de Colombia, 2011.

Terreros Andréu, Carmen. "El expolio de patrimonio cultural: problemas de conceptualización jurídica", Revista electrónica del Patrimonio Histórico, n. ${ }^{\circ}$ 14, Granada: Universidad de Granada, 2014.

Vaquer Caballería, Marcos. "La protección jurídica del patrimonio cultural inmaterial", Revista Museos.es, n. ${ }^{\circ}$ 1, Madrid: Ministerio de Cultura, 2005.

Zuluaga Varón, Diana Carolina. El derecho al paisaje en Colombia. Consideraciones para la definición de su contenido, alcance y límites, Bogotá: Universidad del Externado, 2015.

\section{ABREVIATURAS}

C.P. Constitución Política del Perú

LGPCN Ley General del Patrimonio Cultural de la Nación

RLGPCN Reglamento de la Ley General del Patrimonio Cultural de la Nación

LOM Ley Orgánica de Municipalidades

LCMC Ley de Creación del Ministerio de Cultura 